\title{
PENGEMBANGAN LEMBAR KERJA SISWA DENGAN VISUALISASI BERBANTU MACROMEDIA FLASH PADA PEMBELAJARAN MATEMATIKA
}

\author{
Indry Anggraeni Arahim \\ Prodi Magister Pendidikan Matematika, Falkultas FPMIPA, Universitas Tanjungpura \\ Jalan Prof. Dr. Hadari Hawawi Pontianak \\ e-mail: anggraeni3146@gmail.com
}

\begin{abstract}
Abstrak
Tujuan penelitian adalah untuk mengetahui keefektifan penggunaan media LKS digital dengan visualisasi berbantuan macromedia flash dalam pembelajaran Matematika. Penelitian dilaksanakan di SMP Negeri 40 Semarang pada semester genap. Subjek penelitian adalah siswa kelas VIII D dan VIII E. Jenis penelitian yang digunakan adalah penelitian R\&D. Penelitian dilakukan dengan dua tahap. Tahap pertama untuk pengembangan produk menggunakan model ADDIE dan tahap kedua untuk menguji keefektifan produk melalui tes uji coba. Uji keefektifan dapat dilihat dengan uji-t pihak kanan. Teknik pengumpulan data menggunakan pengukuran dan komunikasi tidak langsung. Alat pengumpulan data menggunakan tes dan angket. Hasil penelitian yaitu pembelajaran menggunakan LKS digital dengan visualisasi berbantu macromedia flash lebih efektif daripada pembelajaran konvensional.
\end{abstract}

Kata Kunci: LKS, macromedia flash, visualisasi.

\begin{abstract}
The purpose of the study was to determine the effectiveness of using digital LKS media with macromedia flash assisted visualization in Mathematics learning. The study was conducted in Semarang Public Middle 40 in the even semester. The research subjects were students of class VIII D and VIII E. The type of research used was $R \& D$ research. The study was carried out in two stages. The first stage for product development uses the ADDIE model and the second stage is to test the effectiveness of the product through a trial test. The effectiveness test can be seen with the right-party t-test. Data collection techniques use indirect measurement and communication. Data collection tools use tests and questionnaires. The results of the study, namely learning to use digital LKS with macromedia flash-assisted visualization is more effective than learning convention.
\end{abstract}

Keywords: student worksheet, macromedia flash, visualization.

\section{PENDAHULUAN}

Masalah besar yang dihadapi oleh pendidikan nasonal antara lain persoalan mutu, relevansi, evektivitas, dan efisiensi pendidikan. Masalah-masalah tersebut menimbulkan keselarasan pada masyarakat yang sering kali terdengar dalam diskusi, seminar, lokakarya, dan terbaca dalam surat kabar, majalah, jurnal, dan sebagainya. Keselarasan tersebut (bahwa pendidikan masih rendah mutunya, kurang revalansinya dengan kebutuhan pembangunan, kurang evektif dan efisien 
pelaksanaannya) harus segera ditanggapi secara serius dan dipecahkan secara komperehensif dan terpadu demi suksesnya pendidikan dan juga berati pembangunan bangsa.

Masalah lain yang dihadapi dunia pendidikan adalah lemahnya proses pembelajaran. Dalam proses pembelajaran anak kurang didorong untuk mengembangkan kemampuan berpikir. Proses pembelajaran di dalam kelas diarahkan kepada kemampuan anak untuk menghafal informasi. Otak anak dipaksa untuk mengingat dan menimbun berbagai informasi tanpa dituntut untuk memahami informasi yang diingatnya tanpa dihubungkan dalam kehidupan sehari-hari.

Perubahan dan pengembangan ilmu pengetahuan dan teknologi yang semakin pesat perlu direspon oleh kinerja pendidikan yang diperlukan untuk mendukung terciptanya manusia yang cerdas dan terampil agar bisa bersaing secara terbuka diera global. Kinerja pendidikan menuntut adanya pembenahan dan penyempurnakan terhadap aspek subtansif yang mendukungnya, yaitu kurikulum dan tenaga profesional yang melaksanakan kurikulum tersebut yaitu guru.

Perkembangan ilmu pengetahuan dan tekhnologi juga tidak terlepas dari ilmu-ilmu dasar yang merupakan dasar dari pola pikir manusia, salah satunya adalah matematika. Matematika telah berkembang sangat luas dan tidak sedikit cabang Matematika digunakan oleh bidang studi lain dalam memecahkan suatu masalah. Tetapi banyak didapati siswa yang ternyata kurang menyukai pelajaran Matematika. Siswa beranggapan bahwa pelajaran Matematika sulit dan membingungkan karena matematika bersifat abstrak. Oleh karenanya dibutuhkan peran guru dalam menentukan model pembelajaran yang sesuai dengan materi yang diajarkan. Tidak sedikit pendidik yang mengunakan teknik menghafal dalam mengajar dan siswa masih merujuk pada satu sumber belajar saja yaitu guru. Belajar lebih bermakna jika siswa mengalami apa yang dipelajari, bukan mengetahuinya.

Menurut Prastowo (2012:83) bahan ajar yang dikembangkan harus memberikan pengalaman kepada peserta didik. Ragam media, sumber belajar, 
aktivita,s dan umpan balik adalah komponen penting untuk membuat bahan ajar yang menarik. Presentasi merupakan hal yang sangat mudah bagi berbagai kalangan. Akan tetapi mendapatkan hasil presentasi yang memuaskan sehingga apa yang dipresentasikan mendapat buy in dari hal layak sangat mudah. Oleh karenanya perlu dikembangkan keterampilan presentasi yang baik.

Salah satu sumber belajar yang digunakan dalam penilitian adalah lembar kerja siswa (LKS). LKS adalah lembaran-lembaran yang berisi tugas yang harus dikerjakan oleh peserta didik. LKS dalam penelitian tidak seperti terlihat pada umumnya. LKS dipadukan visualisasi dengan software macromedia flash. Bentuk komunikasi visual dapat menarik pemirsa dibandingkan apabila disampaikan secara verbal. Dengan demikian, sasaran dapat lebih berkonsentrasi kepada objek yang sedang disajikan. Hal tersebut sangat penting dalam suasana instruksional yang memerlukan konsentrasi yang penuh dari pihak sasaran agar dapat mengikutinya. Banyak software yang dapat membantu melakukan presentasi secara digital. Salah satunya adalah macromedia flash. Macromedia flash memiliki nilai yang lebih dalam manajemen warna, komponen, dan windows inspector.

Berdasarkan uraian latar belakang yang telah diuraikan, maka penulis tertarik untuk mengadakan penelitian tentang pengembangan LKS dengan visualisasi berbantu macromedia flash dalam embelajaran Matematika. Berdasarkan pemaparan dalam latar belakang, maka permasalahan yang muncul adalah motivasi dalam belajar Matematika yang cenderung rendah menyebabkan menurunnya minat belajar siswa dalam pembelajaran Matematika. Siswa menganggap Matematika pelajaran yang banyak rumus sehingga terkesan sulit dan rumit. Kurangnya visualisasi materi Matematika yang disajikan dalam kehidupan sehari-hari dan proses belajar siswa yang hanya menggunakan sumber belajar yang hanya disediakan oleh sekolah.

Tujuan penelitian adalah untuk mengetahui cara mengembangkan LKS digital, hasil belajar siswa, dan keefektifan penggunaan LKS dengan visualisasi berbantuan macromedia flash. 


\section{METODE}

Penelitian dilaksanakan di SMP Negeri 40 Semarang pada semester genap. Subjek penelitian adalah siswa kelas VIII D dan VIII E. Jenis penelitian yang digunakan adalah penelitian research and development (R\&D). Penelitian dilakukan dengan dua tahap. Tahap pertama untuk pengembangan produk menggunakan model ADDIE dan tahap kedua untuk menguji keefektifan produk melalui tes uji coba.

Desain eksperimen yang pertama adalah before-after yaitu uji coba produk yang dilakukan dengan menggunakan desain one-group pretest-posttest dan yang kedua adalah posttes-only control design. Teknik pengumpulan menggunakan pengukuran dan komunikasi tidak langsung. Alat pengumpulan data menggunakan tes dan angket. Tes digunakan untuk mengetahui nilai hasil belajar siswa dan angket digunakan untuk mengetahui tanggapan siswa terhadap media LKS digital dengan visualisasi berbantu macromedia flash.

Teknik analisis data menggunakan analisis awal dan analisis akhir. Pada analisis tahap awal yang dilakukan yaitu dengan menguji normalitas sampel dan uji normalitas sampel. Sedangkan pada tahap ahir yaitu uji normalitas, uji homogenitas, dan uji hipotesis.

\section{HASIL DAN PEMBAHASAN}

Peniliti mengembangkan LKS yang awalnya berupa cetak diubah menjadi LKS berbentuk digital dengan mengunakan macromedia flash. Peneliti juga menggunakan visualisasi. Visualisasi yang dimaksud adalah mengunakan audio visual. LKS digital yang dihasilkan juga terdapat musik dan animasi. Musik bertujuan untuk membuat dalam pembelajaran tidak membosankan sedangkan visualisasi untuk mempermudah pemahaman siswa dalam mempelajari materi kubus yang dianggap abstrak sehingga kesulitan siswa dapat diatasi. Peneliti juga mengunakan model pengembangan ADDIE. Dalam model ADDIE peniliti harus melewati lima langkah. Berikut akan dipaparkan setiap langkah dalam model tersebut. 
Tahap analysis yang dilakukan adalah melakukan identifikasi tujuan umum pembelajaran yang harus dicapai siswa dalam materi kubus. Kemudian melakukan analisis kebutuhan berupa menentukan kompetensi-kompetensi yang harus dicapai oleh siswa. Tahap selanjutnya adalah design. Pada tahap design peneliti mendesain produk yang akan dipakai dalam proses pembelajaran. Produk yang akan didesain untuk penelitian yaitu dengan mengembangkan LKS digital dengan visualisasi berbantu macromedia flash pada materi kubus SMP Negeri 40 Semarang kelas VIII semester II.

Tahap selanjutnya adalah development (pengembangan) yang meliputi kegiatan membuat dan memodifikasi perangkat pembelajaran. Perangkat pembelajarannya adalah media LKS digital dengan visualisasi berbantu macromedia flash pada pembelajaran Matematika untuk tujuan pembelajaran yang telah ditentukan. Tahap berikutnya adalah implementasi. Peneliti menerapkan pembelajaran dengan media LKS digital dengan visualisasi berbantu maceromedia flash pada pembelajaran Matemaika pada materi kubus kelas VIII semester II.

Tahap terakhir adalah evaluasi. Peneliti membandingkan nilai siswa pada saat pretest (diambil dari nilai ulangan semester gasal) dan posttest. Setelah mengetahui perbedaan/selisih nilai tersebut, maka akan diketahui bagaimana tingkat keefektifan program pembelajaran dengan menggunakan media LKS digital dengan visualisasi berbantu macromedia flash. Pada tahap evaluasi, seluruh siswa juga memberikan tanggapannya terhadap media LKS digital dengan visualisasi berbantu macromedia flash.

Hasil pengujian pruduk pada kelompok kecil diperoleh rata-rata hasil pretest sebesar 79,00 dan rata-rata hasil posttest sebesar 87,00. Berdasarkan kedua hasil uji coba dilakukan uji-t berpasangan. Sehingga diperoleh t hitung sebesar 2,4490, sedangkan pada $=5 \%$ dengan $\mathrm{dk}=(\mathrm{n}-1)=10-1=9$ diperoleh $\mathrm{t}_{\text {tabel }}=1,83$ sehingga $\mathrm{H}_{0}$ ditolak. Dengan demikian dapat disimpulkan bahwa rata-rata nilai siswa setelah menggunakan media LKS digital dengan visualisasi berbantu macromedia flash lebih baik dari pada sebelum menggunakan media LKS digital dengan visualisasi berbantu macromedia flash. 
Pada kelas eksperimen dan kontrol diperoleh hasil rata-rata kelas eksperimen sebesar 86,56 dan rata-rata kelas kontrol sebesar 80,47 yang telah diuji normalitas data maupun homogenitas data hasil evaluasinya. Dari rata-rata tersebut dilakukan uji t pihak kanan sehingga diperoleh nilai t hitung sebesar 2,2237. Berdasarkan daftar distribusi $\mathrm{t}$ dengan derajat kebebasan didapat dalam taraf nyata 0,05 , maka dapat disimpulkan bahwa rata-rata nilai evaluasi (posttest) siswa kelas eksperimen lebih baik dari pada rata-rata nilai evaluasi (posttest) siswa kelas kontrol.

Dengan demikian dari hasil validasi ahli media, ahli materi pembelajaran, responden siswa, dan hasil tes kemampuan awal (pretest), dan tes kemampuan akhir (posttest) pada kelompok kecil, serta hasil posttest pada kelompok besar, jadi LKS digital dengan visualisasi berbantu macromedia flash secara valid dapat digunakan dalam proses pembelajaran Matematika serta efektif sebagai media pembelajaran Matematika pada pokok bahasan kubus pada siswa kelas VIII SMP Negeri 40 Semarang. Hal tersebut disebabkan karena dalam penggunaaannya media pembelajaran LKS digital dengan visualisasi berbantu macromedia flash mengunakan komputer yang membuat siswa lebih senang dan aktif serta visualisasi, animasi dan musik yang mendukung di dalam LKS digital dengan visualisasi berbantu macromedia flash sehingga menambah daya tarik dan semangat siswa dalam belajar.

Hasil penelitian yang dilakukan sejalan dengan hasil penelitian oleh Arika (2013) yang menyatakan bahwa hasil belajar siswa dengan menggunakan modul digital berbantuan macromedia flash lebih baik dibandingkan dengan hasil belajar siswa yang melaksanakan pembelajaran konvensional. Hasil penelitian oleh Resti (2013) juga menyatakan bahwa hasil belajar siswa yang mendapatkan pembelajaran menggunakan LKS digital hasil pengembangan lebih baik dibandingkan siswa yang memperoleh pembelajaran dengan pembelajaran konvensional, serta hasil penelitian oleh Al-Hikmah (2013) yang menyatakan bahwa hasil belajar siswa yang mendapat pembelajaran dengan menggunakan 
modul Matematika dengan pendekatan kontekstual dilengkapi visualisasi gambar ilustrasi lebih baik dari hasil belajar siswa sebelum menggunakan modul.

Berdasarkan hasil penelitian dan pembahasan, penggunaan LKS digital dengan visualisasi berbantu macromedia flash efektif untuk digunakan dalam pembelajaran Matematika materi kubus. Hasil belajar siswa dengan menggunakan LKS digital dengan visualisasi berbantu macromedia flash lebih baik dibandingkan dengan hasil belajar siswa yang melaksanakan pembelajaran konvensional. Dengan demikian tujuan dalam penelitian telah tercapai dilihat dari telah terujinya kelayakan dan keefektifan LKS digital dengan visualisasi berbantu macromedia flash untuk dijadikan sebagai media pembelajaran Matematika.

\section{SIMPULAN}

Berdasarkan hasil penelitian, maka dapat disimpulkan bahwa pembelajaran menggunakan LKS digital dengan visualisasi berbantu macromedia flash lebih efektif dari pada pembelajaran konvensional bagi siswa kelas VIII di SMP N 40 Semarang. Hal tersebut ditunjukkan dengan nilai rata-rata hasil pretest sebesar 79 dan rata-rata hasil posttest sebesar 87.

\section{DAFTAR PUSTAKA}

Al-Hikmah. 2013. Modul Matematika dengan Pendekatan Kontekstual Dilengkapi Visualisasi Gambar Ilustrasi pada Materi Balok dan Kubus SMP Kelas VIII Semster 2 Tahun Ajaran 2012/2013. Skripsi tidak dipublikasikan. IKIP PGRI Semarang.

Arika, F. M. 2013. Pengembangan Modul dengan Pendekatan Matematika Realistik berbantuan Macromedia Flashdalam Pembelajaran Matematika Di MTs N 1 Semarang. Skripsi tidak dipublikasikan. IKIP PGRI Semarang.

Prastowo, Andi. 2012. Pengembangan Sumber Belajar. Yogyakarta: Pedagogja.

Resti, W. 2013. Pengembangan Lembar Kerja Siswa (LKS) Berbasis Konteksual berbantu CD Interaktif pada Materi Bangun Ruang Sisi Datar Kelas VIII SMP N 2 Margorejo Pati. Skripsi tidak dipublikasikan. IKIP PGRI Semarang.

Rusli. 2009. Teknologi dan Informasi dalam Pendidikan. Jakarta: GP Pres. 
Edukasi: Jurnal Pendidikan, Vol. 16, No. 1, Juni 2018

Sastrawijaya, T. 1991. Pengembangan Program pengajaran. Jakarta: Rineka Cipta.

Suyanto, M. 2005. Multimedia Alat untuk Meningkatkan Keunggulan Bersaing. Yogyakarta: Andi.

Yusuf, P. 2010. Kumunikasi Intruksional. Jakarta: Bumi Aksara. 